Edukacja Dorostych 2021, $n r 2$

ISSN 1230-929 X

http://dx.doi.org/10.12775/ED.2021.016

\author{
Matgorzata Kamińska
}

ORCID: 0000-0003-1768-021X

\title{
POSTAWY PROINNOWACYJNE NAUCZYCIELI - ELEMENTY TEORII I BADAŃ
}

\begin{abstract}
Słowa kluczowe: nauczyciel, innowacyjność, edukacja, badania
Streszczenie: W artykule przedstawiono pedeutologiczny aspekt innowacyjności w edukacji. Na początku nawiązano do dokumentów strategicznych UE oraz zapisów dotyczących działań na rzecz podnoszenia poziomu innowacyjności w edukacji. Następnie omówiono cechy charakteryzujące postawę proinnowacyjną człowieka w kontekście takich pojęć jak kreatywność i innowacyjność. Wskazano na czynniki warunkujące postawę proinnowacyjną. W głównej części artykułu skupiono się na różnych płaszczyznach działalności innowacyjnej nauczycieli i ich stosunku do twórczości i kreatywności. Zwrócono uwagę na postawy nauczycieli wobec zachowań twórczych uczniów. Ważnym elementem jest próba diagnozy czynników kształtujących innowacyjność nauczycieli - w ujęciu systemowym i osobowym. W analizie wykorzystano wybrane wyniki dotychczasowych badań.
\end{abstract}

\section{Wprowadzenie}

W perspektywie minionych 10 lat jednym z kluczowych celów strategicznych Unii Europejskiej w obszarze polityki edukacyjnej było „zwiększanie kreatywności i innowacyjności, w tym przedsiębiorczości, na wszystkich poziomach kształcenia i szkolenia. (...) Kreatywność nie tylko sprzyja samorealizacji, lecz także jest podstawowym źródłem innowacyjności, ta zaś jest uznawana za jedną z głównych sił napędowych zrównoważonego rozwoju gospodarczego. Kreatywność i innowacyjność są kluczowe dla rozwoju przedsiębiorstw i konkurencyjności Europy na rynkach światowych" (Konkluzje Rady UE, 2009). W Komunikacie Komisji Europejskiej z września 2020 roku podkreślono, że „nauczyciele, trenerzy i kadra pedagogiczna są sercem edukacji. Odgrywają najważniejszą rolę w uczynieniu z edukacji owocnego doświadczenia dla wszystkich uczniów. Miliony nauczycieli w całej Europie musiały szybko przystosować się do zamykania szkół z powodu pandemii Covid-19. Pozostali na pierwszej linii reakcji, aby zapewnić 
kontynuację nauki, wprowadzając innowacje do nauczania na odległość dla swoich uczniów przebywających w zamknięciu. Bez nauczycieli i szkoleniowców nie ma innowacji, integracji ani transformacyjnych doświadczeń edukacyjnych dla uczących się. Wizja zawodu nauczyciela w Europejskim Obszarze Edukacji jest wizją wysoce kompetentnych i zmotywowanych nauczycieli, którzy mogą korzystać z szeregu wsparcia i możliwości rozwoju zawodowego w trakcie swojej różnorodnej kariery" (Komunikat KE, 2020). Wspomniano tam również o ustanowieniu „Europejskiej Nagrody Innowacyjnego Nauczania w celu uznania pracy nauczycieli (i ich szkół), którzy wnoszą wyjątkowy wkład w zawód. Inicjatywa ma opierać się na dobrych praktykach, takich jak europejski znak językowy, nagroda im. Jana Amosa Comeniusa, a także krajowe i europejskie nagrody eTwinning" (Komunikat KE, 2020). Z rekomendacji zawartych w Rezolucji Rady UE z lutego 2021 roku wynika, że „aby wspierać innowacje, włączający charakter, jakość i osiągnięcia w kształceniu i szkoleniu, edukatorzy muszą być wysoce kompetentni i zmotywowani, i w tym celu potrzebują szeregu możliwości w zakresie uczenia się, a także wsparcia przez cały okres kariery. Bardziej niż kiedykolwiek należy zwrócić uwagę na dobrostan nauczycieli, trenerów i kadry edukacyjnej w systemach kształcenia i szkolenia, gdyż jest to także jeden z ważnych czynników jakości kształcenia i szkolenia wpływających nie tylko na zadowolenie nauczycieli, ale również na jakość nauczania. Konieczne jest również zwiększenie atrakcyjności i zrewaloryzowanie zawodu nauczyciela, co staje się coraz istotniejsze w związku z niedoborem i starzeniem się nauczycieli w krajach UE. Ponadto przy opracowywaniu korzystnych środowisk i warunków rozwoju kompetencji i motywacji nauczycieli, trenerów i kadry edukacyjnej należy uwzględniać kluczową rolę kadry kierowniczej kształcenia i szkolenia, i tym samym zapewnić, by instytucje kształcenia i szkolenia funkcjonowały jako organizacje uczące się. Inicjatywy, takie jak europejskie akademie nauczycielskie, które zostaną uruchomione za pośrednictwem programu Erasmus+, ułatwią tworzenie sieci kontaktów, dzielenie się wiedzą i mobilność między instytucjami, zapewniając nauczycielom i trenerom możliwości uczenia się na każdym etapie kariery zawodowej, dzielenia się najlepszymi praktykami i innowacyjnymi metodami pedagogicznymi oraz umożliwiając wzajemne uczenie się na skalę europejską" (Rezolucja Rady UE, 2021).

Odnosząc te analizy i założenia strategiczne do polskiej rzeczywistości edukacyjnej w wymiarze pracy nauczycieli i ich potencjału innowacyjności, można zauważyć, że skupiają one, jak w soczewce, bardzo aktualne i ciągle nierozwiązane problemy. Bo czy możemy powiedzieć, że polscy nauczyciele są innowacyjni w swoich działaniach edukacyjnych? Czy otrzymują odpowiednie wsparcie w rozwijaniu innowacyjności, twórczej samorealizacji, doskonaleniu swoich umiejętności innowacyjnego myślenia i działania? Z drugiej strony, czy ich postawy sprzyjają innowacyjności pedagogicznej i chęci uczenia się, pozyskiwania nowej wiedzy, nabywania nowych kompetencji, dzielenia się dobrymi praktykami? Czy innowacyjność traktują li tylko jako instrumentalny wyznacznik pełnionej roli 
zawodowej, atrybut wzmacniający sprawność dydaktyczną, jako element ścieżki awansu zawodowego? Zdaniem Agaty Cudowskiej „nauczyciel postrzegający swoją twórczość tylko w instrumentalnym wymiarze współtworzy niestety szkołę reaktywną, a nie proaktywną, a taka szkoła nie wspomaga ucznia w twórczych poszukiwaniach własnej tożsamości. Wydaje się, że współczesny nauczyciel, aby mógł spełniać swoje zadania staje przed koniecznością przekroczenia takiego paradygmatu w kierunku budowania twórczej filozofii własnego życia, z której dopiero wyłania się potrzeba twórczego rozwoju zawodowego" (A. Cudowska, 2004, s. 214). Kształtowaniu twórczej orientacji życiowej nauczyciela, a co za tym idzie ujawnianiu wewnętrznej, osobistej potrzeby innowacyjności, z pewnością nie służy presja czasu i osiągnięć, niski prestiż i mała atrakcyjność zawodu, brak uznania i nacisk na biurokratyczne wypełnianie obowiązków szkolnych. Nieustanne obniżanie dobrostanu społecznego i zawodowego nie zachęca do bycia innowacyjnym nauczycielem, nie motywuje do bycia jednostką twórczą.

\section{Postawa proinnowacyjna i jej wyznaczniki}

W innowatyce (teorii innowacji) przyjmuje się różne wyjaśnienia pojęć innowacyjności i postawy proinnowacyjnej człowieka. Innowacyjność w znaczeniu ogólnym można interpretować jako skłonność, gotowość do wytwarzania innowacji. Innowacyjność jednostki bywa też rozumiana jako ,zestaw wewnętrznych oraz nabytych predyspozycji jednostki dotyczących kreowania i wdrażania zmian, prowadzących do podniesienia efektywności jej działalności. Do predyspozycji takich należą m.in. umiejętność uczenia się, zdolność i chęć wprowadzania zmian, zdolność do tworzenia, implementowania i adaptacji innowacji (w tym łatwość akceptowania zmian przychodzących z otoczenia), a także podatność na wpływ czynników zewnętrznych warunkujących takie zachowania" (R. Drozdowski i in., 2010, s. 20). Warto zaznaczyć w tym miejscu, iż w wielu koncepcjach różnicuje się pojęcia innowacyjności i kreatywności, ukazując ich odrębność, współistnienie lub wzajemny wpływ. Według M. Brzezińskiego „innowacyjność to zdolność do pobudzania innowacji (technicznych i organizacyjnych), jest następstwem (w ujęciu czasowym) i wynikiem procesów kreatywności, czyli wykorzystywania efektu twórczego w praktyce" (M. Brzeziński, 2009, s. 36). K. Szmidt pisze o kreatywności ,jako osobowym (personalistycznym) wymiarze twórczości, będącym złożoną syntezą cech poznawczych, emocjonalnych, motywacyjnych oraz zdolności praktycznych jednostki” (K. Szmidt, 2017, s. 12). Kreatywność jest tu utożsamiana z postawą twórczą, „w której myślenie twórcze, motywacja protwórcza oraz działania innowacyjne i zaradność znajdują się w harmonijniej równowadze" (K. Szmidt, 2017, s. 12). Innowacyjność jest postrzegana jako pewien element składowy kreatywności jako postawy twórczej człowieka.

W innej wersji spotykamy zestawienie innowacyjności i kreatywności na zasadzie antagonizowania obu pojęć (tabela 1). 
Tabela 1. Zestawienie cech charakteryzujących pojęcia kreatywności i innowacyjności

\begin{tabular}{|l|l|}
\hline \multicolumn{1}{|c|}{ Kreatywność } & \multicolumn{1}{c|}{ Innowacyjność } \\
\hline $\begin{array}{l}\text { raczej cecha mentalna, opisująca, } \\
\text { jak jednostka myśli (pomysłowo, } \\
\text { twórczo, z wyobraźnią, oryginalnie, } \\
\text { nieschematycznie itd.) }\end{array}$ & $\begin{array}{l}\text { raczej cecha behawioralna, opisująca to, w jaki } \\
\text { sposób jednostka działa (orientując się na zmiany, } \\
\text { implementując nowości itd.) }\end{array}$ \\
\hline $\begin{array}{l}\text { raczej dyspozycja (zatem pewien } \\
\text { potencjał) }\end{array}$ & $\begin{array}{l}\text { raczej umiejętność (zatem coś, co podlega } \\
\text { stosunkowo łatwiejszej obiektywizacji i ocenie, } \\
\text { coś łatwiej wyuczalnego) }\end{array}$ \\
\hline $\begin{array}{l}\text { raczej cecha ,autonomiczna”, nie } \\
\text { powstająca w wyniku interakcji } \\
\text { z otoczeniem i pod jego presją }\end{array}$ & $\begin{array}{l}\text { raczej cecha reaktywna (kształtująca się pod } \\
\text { wpływem zastanych okoliczności, w rezultacie } \\
\text { refleksyjnego monitorowania szans i zagrożeń, } \\
\text { jako reakcja na określone wyzwania itd.) }\end{array}$ \\
\hline $\begin{array}{l}\text { raczej cecha - element myślenia } \\
\text { autotelicznego (bezpośredniego), o celu } \\
\text { jako wartość samej w sobie }\end{array}$ & $\begin{array}{l}\text { raczej cecha - element myślenia } \\
\text { instrumentalnego (pośredniego), o sposobach/ } \\
\text { narzędziach osiągnięcia celu }\end{array}$ \\
\hline $\begin{array}{l}\text { raczej cecha a-sytuacyjna (ujawniająca } \\
\text { się w różnych kontekstach, niekoniecznie } \\
\text { i nie tylko zawodowych i,zadaniowych”) }\end{array}$ & $\begin{array}{l}\text { raczej wymiar kwalifikacji i umiejętności } \\
\text { zawodowych }\end{array}$ \\
\hline $\begin{array}{l}\text { raczej cecha wrodzona (przynajmniej } \\
\text { w potocznym rozumieniu) }\end{array}$ & $\begin{array}{l}\text { raczej cecha nabyta lub ,nabywalna” } \\
\text { /wyuczalna (w potocznym rozumieniu) }\end{array}$ \\
\hline $\begin{array}{l}\text { raczej cecha potencjalnie } \\
\text { „odspołeczniająca”, wyłączająca ze } \\
\text { zbiorowości społeczno-kulturowych } \\
\text { „normalsów” }\end{array}$ & $\begin{array}{l}\text { raczej cecha uspołeczniająca, włączająca } \\
\text { w zbiorowość, więziotwórcza }\end{array}$ \\
\hline $\begin{array}{l}\text { raczej cecha wiązana z orientacją } \\
\text { indywidualistyczną }\end{array}$ & $\begin{array}{l}\text { cecha wiązana raczej z nastawieniem na } \\
\text { kooperację i wspólpracę }\end{array}$ \\
\hline
\end{tabular}

Źródło: Drozdowski R., Zakrzewska A., Puchalska K., Morchat M., Mroczkowska D. (2010), Wspieranie postaw proinnowacyjnych przez wzmacnianie kreatywności jednostki, Warszawa: PARP, s. 21-22.

Innowacyjność klasyfikuje się w kategoriach umiejętności (kwalifikacji zawodowej) nabywanej przez człowieka; jako cechę behawioralną jednostki, która jest zależna od sytuacji i otoczenia. Wiąże się ją z myśleniem instrumentalnym w znaczeniu sposobu lub narzędzi realizacji celu, podkreślając jednocześnie jej prospołeczny aspekt, nastawienie na współpracę i zespołowe działanie. Natomiast kreatywność jest rozumiana jako dyspozycja, potencjał człowieka, możliwy do ujawnienia niezależnie od sytuacji i presji otoczenia. Stanowi element myślenia autotelicznego, z celem jako wartością nadrzędną. Kreatywność w tym znaczeniu nie nosi cech wyuczalności i obejmuje swoim zasięgiem wiele różnych sytuacji 
i obszarów działalności człowieka. Postrzega się ją jako dyspozycję ekskluzywną społecznie, przynależną indywidualistom, którzy raczej stronią od pracy w grupie.

Nie zmienia to jednak zasadniczo podejścia, w którym akcentuje się kreatywność jako niezbędny, choć niewystarczający grunt rozwijania innowacyjności. Swoistym łącznikiem pomiędzy kreatywnością a innowacyjnością jest postawa proinnowacyjna, czyli żywotne zainteresowanie urzeczywistnieniem kreatywnych pomysłów czy idei połączone z gotowością do wzięcia na siebie całości lub części odpowiedzialności za ich wdrożenie (R. Drozdowski i in., 2010, s. 109). Postawa proinnowacyjna człowieka cechuje się otwartością na nowe rozwiązania, przejawia się m.in. umiejętnością uczenia się, gotowością do podejmowania ryzyka, krytycyzmem wobec zastanych schematów i standardów postępowania (R. Drozdowski i in., 2010, s. 20). W podobny sposób odnosi się J. Kozielecki do kategorii człowieka innowacyjnego, który „,charakteryzuje się postawą badawczą pozwalającą wykrywać problemy i je rozwiązywać. System nabywania wiedzy przez jednostkę innowacyjną jest specyficzny (produktywny), tzn. że znaczną część wiedzy nabywa drogą naturalną, w toku bezpośredniego doświadczenia, w toku refleksji, a z uzyskanych informacji z różnych źródeł korzysta podczas rozwiązywania problemów. W ten sposób staje się podmiotem działania, przejawia przedsiębiorczość, dokonuje wyborów, bierze na siebie odpowiedzialność. W efekcie ma poczucie sprawstwa i zadowolenia z życia, motywację do działania oraz nabywa umiejętności sprzyjające samokształceniu" (J. Kozielecki, 1996, s. 49).

Podmiotowy charakter działania człowieka innowacyjnego oraz rozwinięte krytyczne myślenie wiążą się z jego autonomią w wyzwalaniu się postawy twórczej, proinnowacyjnej. Według A. Cudowskiej ,są to co najmniej dwa rodzaje niezależności, uwolnienie się, jako wyzwolenie: od własnych lęków, kompleksów i uprzedzeń, a także od presji otoczenia" (A. Cudowska, 2004, s. 90). Z jednej strony jest to rzeczywista autonomia (w sensie obiektywistycznym), z drugiej strony ma wymiar subiektywistyczny jako poczucie autonomii, wypływające z identyfikacji z przyjętym systemem wartości oraz jego uwewnętrznienia (A. Cudowska, 2004, s. 90).

W postawie proinnowacyjnej człowieka można zatem identyfikować wiele elementów wspólnych/tożsamych z cechami postawy twórczej. Nawiązując do problemu postaw proinnowacyjnych nauczycieli warto przypomnieć koncepcję $\mathrm{R}$. Schulza, który wyróżnił pięć komponentów twórczej postawy nauczyciela:

1. Wiedzę - twórcze podejście do własnej pracy i jej wyników jest bardziej prawdopodobne u nauczyciela, którego wiedza jest wewnętrznie uporządkowana, operatywna i heterogeniczna.

2. Cechy intelektualne - otwartość, elastyczność myślenia, płynność i oryginalność myślenia, zdolność dostrzegania ładu w otoczeniu, niezależność intelektualna, inteligencja, uzdolnienia.

3. Motywację - osoby posiadające wysoką autonomiczną motywację poznawczą są bardziej aktywne twórczo, zdolne do rozwoju własnych zaciekawień i zainteresowań. 
4. Cechy osobowości - niezależność, poczucie odrębności, odwaga, odpowiedzialność, oryginalność, bycie tolerancyjnym, odporność, wytrwałość, krytycyzm, poczucie własnej kompetencji, aktywność, witalizm, ekspresja, elastyczność.

5. System wartości o orientacji przyszłościowej (realizacja tego, co możliwe), orientacja innowacyjna (aprobata zmian), intelektualizm, indywidualizm i aktywizm (czynny stosunek do rozwiązywania problemów) (R. Schulz, 1994, s. 21).

Powyższa charakterystyka wydaje się kompleksowo opisywać atrybuty poznawcze, osobowościowe, aksjologiczne budujące postawę twórczą, która zarazem stanowi w dużym stopniu odpowiednik postawy proinnowacyjnej. Stosunek człowieka do innowacji kształtuje się w określonej sytuacji innowacyjnej, czyli sytuacji zmiany - społecznej, kulturowej, zawodowej, życiowej. W sytuacji innowacyjnej człowiek może prezentować zarówno postawy pozytywne, jak i negatywne, a także neutralne. Mogą być one tak silne, jak i słabe, lub umiarkowane. Postawy mogą przyjmować postać stereotypów bądź uprzedzeń, odpornych na zmianę, co z kolei ma ścisły związek z zachowaniem człowieka w konkretnej sytuacji innowacyjnej. Pożądane są postawy, które nie obezwładniają, nie powodują reakcji niechęci i braku zaangażowania, czasem czynnego oporu. Optymalnym byłoby przyjęcie postawy pozytywnej (recepcyjnej lub pionierskiej), przejawiającej się w chęci przejmowania innowacji opracowanych i dobrze sprawdzonych lub samodzielnym poszukiwaniu lub inicjowaniu nowych, oryginalnych rozwiązań. W praktyce społecznej i edukacyjnej bywa różnie. Zmiana w otoczeniu i konieczność przeformułowania sposobów myślenia i działania zazwyczaj wzbudza niepokój, niepewność, czasem także opór i konflikty interesów, ponieważ narusza istniejący porządek rzeczy, destabilizuje, wymaga wysiłku, pracy, uczenia się nowych umiejętności, rozwiązywania nieznanych problemów.

\section{Innowacyjność i kreatywność nauczycieli}

W projektowaniu postaci innowacyjnego nauczyciela, który nie boi się zmian i nowych wyzwań, można posługiwać się różnorodnymi teoriami i paradygmatami naukowymi oraz wskazaniami praktyki szkolnej. Można mówić o nauczycielu, który potrafi efektywnie wykorzystywać dostępną wiedzę i informacje, stosować nowoczesne technologie edukacyjne i metody aktywizujące. Jest świadomy swoich ograniczeń i niedoskonałości, ale jednocześnie nie broni się i nie stawia barier temu, co nowe, nieznane. Zdaje sobie sprawę z potrzeby myślenia i działania perspektywistycznego, nastawionego na innowacyjne strategie edukacyjne. Wie, że umiejętność współdziałania i pracy zespołowej jest odpowiedzią na przejawy autonomizacji i izolacji społecznej. Złożoność i zmienność otaczającego świata wymagają od nauczyciela krytycznego spojrzenia na własną wiedzę, jak również elastycznego i innowacyjnego podejścia do potrzeb uczniów i współczesnej szkoły. Wymaga uczenia się przez całe życie, także w kontekście działalności innowacyjnej - uczenia się dla innowacji i przez innowacje. 
Zdaniem Kazimierza Denka działalność innowacyjną ułatwia nauczycielom rozwinięta wyobraźnia, inicjatywa, pomysłowość w działaniu, umiejętność skoncentrowania się na istotnych faktach, zjawiskach i procesach społecznych, technice i kulturze oraz spora doza nonkonformizmu, czyli niezależność myśli oraz krytycyzm (K. Denek, 2007, s. 12). Dużą rolę przypisuje on również takim cechom jak: naturalność, poczucie humoru, obiektywizm, przedsiębiorczość, odwaga spojrzenia trudnościom w oczy, stała gotowość ich pokonywania własną zaradnością i pomysłowością. Zwraca uwagę na „tworzenie wśród uczniów klimatu rozbudzenia twórczego niepokoju, woli wzbogacania wiedzy, radości poznawczej oraz takiego oceniania postępów w nauce, które ich rozwija, wskazywaniu im co mogli, a co osiągnęli, z czego zrezygnowali, w czym się nie sprawdzili" (K. Denek, 2007, s. 12-13).

Jednak wielu badaczy i ekspertów zwraca uwagę na szereg barier i ograniczeń w przyjmowaniu pozytywnych postaw wobec innowacji wśród (nie tylko polskich) nauczycieli. Dla przykładu w raporcie przygotowanym w 2018 roku dla Ministerstwa Przedsiębiorczości i Technologii wskazuje się na to, iż „największym problemem w rozwoju kompetencji proinnowacyjnych w szkołach jest system egzaminów, który szkodzi zarówno innowacyjności nauczycieli, jak i kreatywności uczniów. Rozwojowi kompetencji proinnowacyjnych (w sposób pośredni) szkodzą także rankingi szkół, ponieważ koncentrują uwagę na tych celach systemu edukacji, które nie są skorelowane z promowaniem postaw proinnowacyjnych. W szczególności chodzi tutaj o atmosferę odkrywania, krytyczne myślenie, rozwijanie chęci do podejmowania ryzyka. Ponadto sama idea nadzoru pedagogicznego, który ma „kontrolować” lub „karać” nauczycieli, stoi w sprzeczności z ideą innowacji. Niektórzy eksperci wskazują jako przyczynę niewystarczającego nacisku na kształtowanie kompetencji proinnowacyjnych w szkołach, niskie zarobki nauczycieli w całej Europie, szczególnie na początku. Dużym problemem jest brak instrukcji i wskazówek dla nauczycieli we wszystkich krajach europejskich, jeżeli chodzi o to, jak nauczać kreatywności. Nauczyciele także często rozumieją kreatywność bardzo wąsko - jako aktywność artystyczną ucznia. W społeczeństwie funkcjonuje także wiele mitów związanych z kreatywnością np. Nie każdy jest kreatywny, Dzieci sa bardziej kreatywne niż dorośli, Myślenie analityczne i myślenie kreatywne sa wobec siebie przeciwstawne, Wszystko, co kreatywne jest oryginalne" (J.A. Fazlagić, 2018, s. 31-35). Widać tu zarówno przeszkody i ograniczenia o charakterze systemowo-organizacyjnym, jak i mentalnościowo-poznawczym. Część z nich nawiązuje do konkluzji i zaleceń zawartych w dokumentach Komisji Europejskiej i Rady Komisji Europejskiej przytoczonych na początku artykułu.

Barierą, która skutecznie utrudnia podejmowanie aktywności twórczej przez uczniów w szkole i poza szkołą, są wymieniane przez K. Szmidta ,zachowania antytwórcze nauczycieli, które można zaobserwować w różnorodnych sferach jego działań szkolnych zarówno w obszarze planowania treści i metod nauczania, jak 
i toku dydaktycznego oraz sposobów oceniania dokonań uczniów. Wiążą się też ze stylem pracy nauczyciela i jego osobowością jako człowieka, który codziennie staje przed innymi, by ich nauczać wiedzy, umiejętności i życia” (K. Szmidt, 2017, s. 18-19). Pierwszy problem to stosunek nauczycieli do uczniów o zdolnościach twórczych. $Z$ badań międzynarodowych wynika, że nauczyciele raczej nie lubią sytuacji (uważając je za kłopotliwe, niewygodne, słabo poddające się kontroli), gdy uczeń przejawia niezależność i oryginalność myślenia, skłonności do zgadywania i spekulowania; gdy dostrzega problem tam, gdzie inni go nie widzą i ma zdolność generowania wielu różnorodnych rozwiązań tego samego problemu. Większość nauczycieli woli kontakt z uczniami grzecznymi, posłusznymi, uprzejmymi, punktualnymi, pilnymi, którzy wykazują się znajomością z różnych dziedzin wiedzy oraz zdolnością do przyjmowania pomysłów innych osób. Druga trudność dotyczy „niewiedzy nauczycieli z zakresu psychologii i pedagogiki twórczości oraz ciągle aktualnej dominacji wśród nauczycieli wielu zdekonspirowanych przez ostatnie badania mitów o twórczości i kreatywności. (...) Nauczyciele, zwłaszcza nauczyciele szkół średnich, są przyzwyczajeni do XIX-wiecznej romantycznej wizji twórczości jako dziedziny zarezerwowanej dla sztuki, a za osobę twórczą uznają jedynie wybitnych artystów, naukowców i wynalazców, których Bóg lub duch obdarował zdolnościami twórczymi, a tych raczej nie da się nauczyć. Tej mitologicznej wiedzy towarzyszy na ogół niski poziom własnej twórczości pedagogicznej” (K. Szmidt, 2017, s. 18-19).

Inne wyniki badań (M. Karwowski, 2008) dotyczące opinii nauczycieli i uczniów o twórczości w szkole są poniekąd zbieżne z diagnozą dokonaną przez K. Szmidta. Na poziomie deklaracji nauczyciele cenią kreatywność uczniów, choć wyjście poza deklaracje pokazuje, że w rzeczywistości z akceptacją bywa gorzej. Zdaniem badaczy nauczyciel jest absolutnie niewiarygodnym źródłem wnioskowania o uczniowskiej kreatywności, wskazania nauczycieli najczęściej dotyczą uczniów dobrze uczących się, nie zaś twórczych. Nauczyciele ze szkół niepublicznych stawiają twórczość wyżej w charakterystyce dobrego ucznia niż ci ze szkół publicznych; atmosfera też jest tam bardziej sprzyjająca dla twórczości. Te same pomysły twórcze uczniów nauczyciele oceniają różnie w zależności od tego, czy autor pomysłu przedstawiany jest jako osoba twórcza lub nietwórcza.

Stosunek nauczycieli do zachowań twórczych uczniów może mieć swoje źródła w tym, na ile sami nauczyciele wykazują się kreatywnością. Ciekawe badania na ten temat zostały przeprowadzone przez J. Uszyńską-Jarmoc wśród nauczycieli przedszkoli, edukacji wczesnoszkolnej oraz kandydatów na nauczycieli. Ogólne wyniki pomiaru kreatywności u 163 badanych osób pokazały niski poziom we wszystkich grupach. Sprawdzano również, na ile kreatywność jako pożądana cecha współczesnego nauczyciela jest związana z pożądanym modelem jego interakcji wychowawczych z dzieckiem w wieku przedszkolnym. Okazało się, że korelacja jest umiarkowana, istotna statystycznie, co oznacza, że im wyższy poziom kreatywności nauczyciela, tym bardziej pozytywne były deklarowane przekonania 
i zachowania nauczycieli i kandydatów na nauczycieli podejmujących interakcje wychowawcze z dziećmi (J. Uszyńska-Jarmoc, 2014, s. 76-78). Jeśli jednak poziom kreatywności jest na niskim poziomie, to można się spodziewać, że postawy nauczycieli wobec innowacji oraz ich praktyczna działalność innowacyjna również nie będzie zadowalająca.

W świetle badań przeprowadzonych wśród nauczycieli przez B. Strycharską-Gać (za: M. Kazimierowicz 2008) na temat ich praktycznej działalności innowacyjnej w ramach swojego przedmiotu, większość z nich deklaruje wykorzystywanie metod aktywizujących (m.in. burza mózgów, metoda projektów, drama, mapa skojarzeń, myślące kapelusze). Wśród innych pomysłów są: korzystanie z Internetu, korelacja z innymi przedmiotami, programy multimedialne, elementy dziennikarskich metod pracy, prowadzenie lekcji w terenie. Poza wykorzystywaniem technik twórczego myślenia w obszarze metod aktywizujących uczniów na zajęciach trudno doszukać się tu szczególnej innowacyjności w edukacji. Czyżby przyczyna takiego stanu tkwiła w słabej sprawności dydaktycznej w obszarze pedagogiki innowacyjności? A może chodzi właśnie o niedostatek wiedzy w zakresie twórczości? Odpowiedzi częściowo można odnaleźć w badaniach przeprowadzonych przez D. Ekiert-Oldroyd w grupie studentów - nauczycieli o krótkim stażu pracy i studentów nie będących nauczycielami. Wykazano, iż poziom wiedzy o twórczości w obu grupach był w większości przeciętny. Badano także postawy respondentów wobec nauczania twórczego. Studenci - nauczyciele deklarowali raczej postawy pozytywne, natomiast wśród pozostałych studentów ten wskaźnik był nieco niższy. Większość z nich prezentowała postawy neutralne, co oznacza, że nie są w pełni przekonani, że ich rolą jest rozwijanie kreatywności uczniów. Badaczka też zwróciła uwagę na rozkład wyników dotyczących postaw negatywnych - prawie $40 \%$ studentów - nauczycieli i niespełna 30\% studentów niebędących nauczycielami wskazała na postawy umiarkowanie i zdecydowanie negatywne. Można zatem przypuszczać, że taki stan znajduje odzwierciedlenie w pracy zawodowej nauczycieli na płaszczyźnie innowacyjnych metod i technik nauczania, a także, jak wnioskuje autorka, jest efektem ,zbyt małego nacisku w procesie kształcenia akademickiego na problematykę kreatywności, nowoczesnego podejścia do twórczości, innowacyjności” (D. Ekiert-Oldroyd, 2014, s. 50-54). Poziom wiedzy o twórczości i samoocena własnego potencjału twórczego były także przedmiotem badań J. Bałachowicz zrealizowanych w grupie 460 nauczycieli wczesnej edukacji. Wyniki pokazały niski poziom wiedzy nauczycieli o twórczości, zwłaszcza w odniesieniu do przebiegu procesu twórczego. Jednocześnie ich samoocena możliwości twórczych była stosunkowo wysoka. Postawy nauczycieli nie różniły się w sposób istotny statystycznie pod względem miejsca zamieszkania czy rodzaju ukończonych studiów. Pewne tendencje różnicujące stwierdzono w przypadku stażu pracy zawodowej. Wynik całkowity poziomu wiedzy o twórczości nieznacznie wzrastał wraz ze stażem pracy, podobnie jak samoocena potencjału twórczego. Ciekawe wnioski uzyskano w kwestii korelacji między wskaźnikami osobowości 
twórczej i preferowanym stylem poznawczym a poziomem wiedzy o twórczości badanych nauczycieli. Dla przykładu nauczyciele, którzy preferują postawę badawczą w uczeniu się własnym i swoich uczniów, nie zawsze wykazują się wiedzą na temat twórczości, a nauczyciele akceptujący autorytaryzm w zdobywaniu wiedzy rzadziej określają siebie jako osobę twórczą i nie dostrzegają potrzeby tworzenia klimatu sprzyjającego zachowaniom kreatywnym swoich uczniów. Na podstawie analizy badań autorka wysuwa przypuszczenie, iż „nauczyciele o adaptacyjnym stylu poznawczym będą bardziej skłonni uznawać kreatywność za dyspozycje dzieci osiągających wysokie wyniki w nauce czy wyróżniającymi się specjalnymi zdolnościami, np. literackimi lub plastycznymi, a nie będą skłonni traktować kreatywności jako dyspozycji egalitarnej” (J. Bałachowicz, 2013, s. 117-126).

Nie napawa optymizmem fakt, że nauczyciele dysponują niskim poziomem wiedzy pedagogicznej i psychologicznej o twórczości, a ich przekonania, wśród których nie brakuje poglądów stereotypowych i dyskryminujących zachowania twórcze uczniów, często są istotnymi czynnikami spowalniającymi, a może nawet hamującymi rozwój innowacyjności w edukacji. Z drugiej strony cieszą wyniki badań B. Dyrdy, w których studenci pedagogiki uczestniczący w zajęciach z przedmiotu fakultatywnego Techniki twórczego rozwiąywania problemów dostrzegają jednak „konieczność rozwijania twórczego myślenia przyszłych nauczycieli, jak również możliwości i celowość wykorzystania metod twórczego rozwiązywania problemów w profesji nauczycielskiej” (B. Dyrda, 2008, s. 75).

W kwestii istniejących barier w kształtowaniu postaw i kompetencji proinnowacyjnych nauczycieli warto zauważyć, że w opinii wielu badaczy i ekspertów, nie służą temu sposoby organizacji pracy dydaktycznej szkoły, które zazwyczaj przejawiają się w takich działaniach jak: promowanie powierzchownego uczenia się (shallow learning) w kontekście zaliczania sprawdzianów i zdawania egzaminów; posługiwanie się przez nauczycieli „programem nauczania” i treściami „do przerobienia”, co dla przeciętnego ucznia wiąże się jedynie z przymusem i kontrolą; nauczanie treści zdezaktualizowanych, oderwanych od rzeczywistości; podział na przedmioty, a co za tym idzie niedobór realizacji interdyscyplinarnych projektów w różnych konfiguracjach; zabijanie spontaniczności w rozwiązywaniu problemu i promowanie imitacji zachowań uznawanych za poprawne; hołdowanie uproszczonym, sztucznym opisom (schematom) (J.A. Fazlagić, 2018, s. 146-147). Kolejne przykłady barier innowacyjności w ujęciu systemowo-organizacyjnym przytacza B. Przyborowska. W kontekście pracy nauczyciela i postaw proinnowacyjnych warto zwrócić uwagę na takie czynniki, jak: wieloznaczność i wielowymiarowość zadań szkoły, co powoduje dezorientację i przeciążenie nauczycieli, a w konsekwencji brak możliwości skupienia się na działalności innowacyjnej; hermetyczność środowiska szkolnego, brak upowszechnienia kultury innowacyjności; niedostateczna współpraca między szkołami w zakresie wymiany doświadczeń innowacyjnych, rywalizacja; postawy antyinnowacyjne rodziców, niechęć 
do przyjmowania nowości; ocenianie pracy szkoły (nauczycieli) na podstawie wskaźników ilościowych, zapominanie o aspektach jakościowych; niepewność pozycji nauczycieli innowatorów, obawa przed ostracyzmem i brakiem akceptacji ze strony przełożonego; kult pedagogicznego doświadczenia, rutynizowanie swojej działalności, brak refleksyjności, brak wsparcia grona pedagogicznego (B. Przyborowska, 2013, s. 240-241).

Z pewnością nie wszystkie wymienione powyżej bariery i trudności są bezpośrednio uzależnione od samego nauczyciela. Mają one w większości charakter systemowy, co nie oznacza, że nauczyciele są zupełnie pozbawieni sprawczości i decyzyjności w tym zakresie. Przy zwiększeniu poziomu świadomości i zaangażowania szerszych środowisk nauczycielskich (a nie tylko pojedynczych nauczycieli) można by uniknąć lub ograniczyć działanie czynników niesprzyjających postawom proinnowacyjnym. W wielu wynikach badań eksponuje się mentalnościowe, psychologiczne bariery w procesie wdrażania innowacji edukacyjnych, odnoszące się właśnie do samych nauczycieli. Korespondują one z refleksjami badawczymi K. Szmidta, o których była mowa we wcześniejszych fragmentach artykułu. Dla przykładu badaczki z Uniwersytetu Łódzkiego dokonały analizy treści wywiadów z 12 edukatorami, uznawanymi w środowisku za innowatorów. Byli to m.in. założyciele autorskich szkół eksperymentalnych, ośrodków innowacji edukacyjnych oraz twórcy innowacyjnych programów edukacyjnych, animatorzy społeczności lokalnych, a także autorzy podręczników i alternatywnych metod nauczania. Zwracali oni uwagę na aspekt mitów edukacyjnych, które determinują sposoby myślenia i działania nauczycieli. W opinii badanych stanowią one poważne ograniczenia w innowacyjności nie tylko nauczyciela, ale przede wszystkim szkoły jako systemu twórczego. Zdaniem innowatorów nie istnieją realne przeszkody nie do pokonania, a raczej są generowane przez ludzkie przekonania i tradycję, które impregnują nauczycieli na odmienność, nowość, zmianę (A. Chmielińska, M. Modrzejewska-Świgulska, 2018, s. 23).

Warto zatem upowszechniać wiedzę wśród nauczycieli i studentów na temat obiegowych, często błędnych poglądów na temat twórczości. Wydaje się, że kluczową rolę do odegrania mają tu nauczyciele akademiccy w uczelniach pedagogicznych, konsultanci i metodycy, edukatorzy i trenerzy w ośrodkach doskonalenia nauczycieli. Z drugiej strony, jak zauważa M. Skorobogata, ,przygotowanie metodyczne i dydaktyczne nauczycieli bez kształcenia w nich świadomości sensu własnych działań (...) nie wystarcza do pracy z młodymi ludźmi w sposób zadowalający i efektywny. Dobrym kierunkiem do lepszej jakości ich pracy jest więc samoświadomość, refleksja i poczucie „niedomkniętych kwalifikacji”. Wykształcenie często poza kwalifikacjami wyposaża również w zbytnie zaufanie do swych możliwości, umiejętności i wiedzy. Staje się ono wówczas balastem, obciążającym nie tylko nauczycieli, ale i powierzone im osoby. Dlatego tak cenny okazuje się otwarty umysł, który może być cechą niezależną od wieku. Połączony ze stałą uważnością i wrażliwością na drugiego człowieka (pojmowanego w sposób integralny) 
jest atutem dobrze przygotowanego nauczyciela. Ucząc się przez praktykę jesteśmy stale w drodze. Rzeczywistość nieustannie zmieniająca wszystko, co znaliśmy i do czego zostaliśmy przygotowani wymusza w nas postawę bycia nieprzygotowanym (oznaczającą właśnie otwartość i wrażliwość)" (M. Skorobogata, 2012, s. 173). Wyniki badań, ale i doświadczenia praktyczne pokazują, że nauczyciele nie zawsze są w stanie spojrzeć obiektywnie na swój poziom wiedzy, umiejętności; nie zawsze potrafią realnie ocenić własne możliwości twórcze i stosunek do innowacji. Pewnie dotyczy to nie tylko nauczycieli. Jednak postawa proinnowacyjna oznacza otwartość na nowe wyzwania, gotowość do uczenia się, podejmowania ryzyka. Oznacza odwagę w pokonywaniu trudności i odwagę „bycia nieprzygotowanym", uczenie się przyjmowania postawy badacza w pracy i w życiu. Niepewność posiadanej wiedzy nie musi być przeszkodą w działaniu innowacyjnym, ale może stać się impulsem do jej poszukiwania, niekoniecznie w sposób systemowy, formalny - uczymy się przecież w różnych sytuacjach zawodowych i życiowych. Wydaje się, że kluczowe jest uświadomienie sobie własnej niewiedzy i uchwycenie sensu jej poszukiwania. Rodząca się podmiotowość poznawcza w wyniku przyjęcia takiej postawy daje szansę wyzwolenia się z okowów tradycyjnych przekonań i nastawień, krępujących ekspresję i aktywność twórczą.

\section{Zakończenie}

Swego czasu I. Dzierzgowska przekonywała nauczycieli, że „twórcze myślenie muszą zacząć od siebie, ponieważ nie nauczą pasji bez autentycznego zaangażowania. Powinni zachęcać uczniów do stawiania pytań, wspierać próby samodzielnego poszukiwania odpowiedzi, popierać niebanalne rozwiązania, cenić odwagę i umiejętność przeciwstawiania się stereotypom" (I. Dzierzgowska, 2008). Minęło kilkanaście lat, a dziś trudno nie odnieść wrażenia, że zmieniło się niewiele w postawach proinnowacyjnych nauczycieli. Zmieniło się za to sporo w otoczeniu społecznym, kulturowym, gospodarczym. Zmieniły się technologie i systemy produkcji, pojawiło się zapotrzebowanie na nowe zawody i profesjonalne umiejętności. Wiele stereotypów społecznych i kulturowych straciło na aktualności. Czyżby nauczyciele nie byli gotowi na zmiany? Z badań G. Leśniewskiej wśród nauczycieli szczecińskich szkół podstawowych dotyczących poziomu gotowości do zmian wynika, że większość badanych wykazała się pomysłowością, ale stopień optymizmu był u nich dość niski. Nie wykazywali też chęci do podejmowania ryzyka i zaangażowania, entuzjazmu w swojej pracy. Deklaracje większości badanych świadczyły o braku pewności siebie. Niewielu też dysponuje zdolnością adaptacyjną (elastyczność w przystosowaniu się do zmieniających się warunków oraz odporność na niepowodzenia), choć u większości zanotowano optymalny lub wysoki poziom tolerancji na niepewność otoczenia (G. Leśniewska, 2016, s. 47). Orientacja proinnowacyjna ściśle wiąże się ze zmianą, a gotowość do zmian należy do kluczowych kompetencji społecznych. Trudno zatem przewidywać, że 
nauczyciele będą przyjmować postawy proinnowacyjne, nie będąc w pełni gotowymi mentalnie, osobowościowo, ale także gdy nie uzyskają adekwatnego wsparcia w uczeniu się całożyciowym, gdy ich zawód będzie ulegał ciągłej dewaloryzacji i pauperyzacji, co w konsekwencji skutkuje dalszym obniżeniem prestiżu i dobrostanu zawodowego. Brak dopływu nowych, młodych kadr nauczycielskich wkrótce może okazać się zgubny dla systemu edukacji. W tej perspektywie pozostaje zatem mieć nadzieję i wierzyć, że planowane w Unii Europejskiej strategie naprawcze zapobiegną ziszczeniu się tych nie najlepszych scenariuszy, a innowacyjność w edukacji nie będzie udziałem jedynie nielicznej grupki nauczycieli - zapaleńców. Warto o tym pamiętać myśląc o kształceniu do innowacyjności kandydatów do zawodu nauczycielskiego. Postawy proinnowacyjne kiełkują już w momencie przygotowania do pracy pedagogicznej i co ważne, nie kształtują się z dnia na dzień. Powszechnej realizacji idei innowacyjności w edukacji nie wolno odkładać na późniejszy, lepszy czas, bo taki może nie nadejść. Ten plan mogą wprowadzić w życie tylko odważni i niezależnie myślący nauczyciele, dla których twórcza edukacja dzieje się już teraz.

\section{Bibliografia}

Bałachowicz, J. (2013). Wiedza nauczycieli o twórczości. W: I. Adamek, J. Bałachowicz (red.), Kompetencje kreatywne nauczyciela wczesnej edukacji dziecka. Kraków: Oficyna Wydawnicza „Impuls”.

Brzeziński, M. (2009). Organizacja kreatywna. Warszawa: PWN.

Chmielińska, A., Modrzejewska-Świgulska, M. (2018), Bariery w pracy nauczycieli oraz innowatorów edukacyjnych w perspektywie badań pedagogicznych. Edukacja Elementarna w Teorii i Praktyce, Vol. 13, No 2(48).

Cudowska, A. (2004). Kształtowanie twórczych orientacji życiowych w procesie edukacji. Białystok: Trans Humana.

Denek, K. (2007). O innowacjach i ewaluacji w edukacji decyduja kompetentni nauczyciele. W: J. Grzesiak (red.), Ewaluacja i innowacje w edukacji. Autoewaluacja i refleksyjność nauczyciela. Konin: Wydawnictwo PWSZ.

Drozdowski, R., Zakrzewska, A., Puchalska, K., Morchat, M., Mroczkowska, D. (2010). Wspieranie postaw proinnowacyjnych przez wzmacnianie kreatywności jednostki. Warszawa: PARP.

Dyrda, B. (2008). Twórcze rozwiązywanie problemów w kształceniu nauczycieli. W: K. Sujak-Lesz (red.), Kształcenie nauczycieli w szkole Wyższej. Wybrane zagadnienia. Wrocław: Centrum Edukacji Nauczycielskiej Uniwersytetu Wrocławskiego. Pobrane z: http:/www.cen.uni.wroc.pl/dzialalnosc/publikacje\#beata-dyrda-tworcze-rozwiazywanie-problemow-w-ksztalceniu-nauczycieli-w-k-sujak-lesz-red-ksztalcenie-nauczycieli-w-szkole-wyzszej-wybrane-zagadnienia-wroclaw-2008 (23.05.2021).

Dzierzgowska, I. (2008). Szkoła, która interesująco uczy. Dyrektor Szkoły, nr 6.

Ekiert-Oldroyd, D. (2014). Wiedza o twórczości i stosunek do nauczania twórczego jako istotne elementy kompetencji współczesnego nauczyciela. Raport z badań studentów pedagogiki. W: I. Adamek, B. Olszewska (red.), Nauczyciel wczesnej edukacji dziecka wobec czasu zmiany. Łódź: Wydawnictwo Wyższej Szkoły Pedagogicznej. 
Fazlagić, J.A. (2018). Szkoła dla innowatora. Kształtowanie kompetencji proinnowacyjnych, Kalisz: Ośrodek Doskonalenia Nauczycieli.

Karwowski, M. (2008). Radosna twórczość o twórczości. Badajmy kreatywność uczniów-nie twórzmy stereotypów, Meritum, $n r 3$.

Kazimierowicz, M. (2008). Innowacyjność nauczycieli, Nowa Szkoła, $n r 1$.

KOMUNIKAT KOMISJI DO PARLAMENTU EUROPEJSKIEGO, RADY, EUROPEJSKIEGO KOMITETU EKONOMICZNO-SPOŁECZNEGO I KOMITETU REGIONÓW w sprawie utworzenia Europejskiego Obszaru Edukacji do 2025 r. z dnia 30.09.2020, COM/2020/625 final. Pobrane z: https://eur-lex.europa.eu/legal-content/ EN/TXT/?uri=CELEX\%3A52020DC0625 (28.05.2021).

Konkluzje Rady z dnia 12 maja 2009 r. w sprawie strategicznych ram Europejskiej współpracy w dziedzinie kształcenia i szkolenia („ET 2020”) 2009/C 119/02. Pobrane z: https://eur-lex.europa.eu/legal-content/PL/TXT/PDF/?uri=OJ:C:2009:119:FULL\&f rom=HR (28.05.2021)

Kozielecki, J. (1996). O człowieku wielowymiarowym. Eseje psychologiczne. Warszawa: Wydawnictwo Akademickie „Żak”.

Leśniewska, G. (2016). Gotowość do zmiany nauczycieli szansą edukacji XXI wieku. Studia i Prace Wydziału Nauk Ekonomicznych i Zarządzania Uniwersytetu Szczecińskiego, 46/1. Oobrane z: http://bazekon.icm.edu.pl/bazekon/element/bwmeta1.element. ekon-element-000171459394 (21.03.2021).

Przyborowska, B. (2013). Pedagogika innowacyjności. Między teoria a praktyka. Toruń: Wydawnictwo Uniwersytetu Mikołaja Kopernika.

Rezolucja Rady w sprawie strategicznych ram europejskiej współpracy w dziedzinie kształcenia i szkolenia na rzecz europejskiego obszaru edukacji i w szerszej perspektywie (2021-2030) z dnia 26.02.2021, 2021/C 66/01. Pobrane z: https://eur-lex.europa.eu/legal-content/PL/TXT/PDF/?uri=CELEX:32021G0226(01)\&from=PL [dostęp 28.05.2021]

Schulz, R. (1994), Twórczość pedagogiczna: elementy teorii i badań. Warszawa: Instytut Badań Edukacyjnych.

Skorobogata, M. (2012). O przygotowaniu do nieprzygotowania z perspektywy nauczyciela-praktyka. W: B.D. Gołębniak, H. Kwiatkowska (red.), Nauczyciele. Programowe (nie) przygotowanie. Wrocław: Wydawnictwo Naukowe Dolnośląskiej Szkoły Wyższej.

Szmidt, K.J. (2017). Edukacyjne uwarunkowania rozwoju kreatywności, Łódź: Wydawnictwo Uniwersytetu Łódzkiego.

Uszyńska-Jarmoc, J. (2014). Kreatywność nauczycieli i ich przekonania i intencje dotyczące interakcji wychowawczych z dziećmi. W: I. Adamek, B. Olszewska (red.), Nauczyciel wczesnej edukacji dziecka wobec czasu zmiany. Łódź: Wydawnictwo Wyższej Szkoły Pedagogicznej. 


\title{
PRO-INNOVATIVE ATTITUDES OF TEACHERS - ELEMENTS OF THEORY AND RESEARCH
}

Key words: teacher, innovation, education, research.

\begin{abstract}
The article presents the pedeutological aspect of innovation in education. At the beginning, reference was made to the EU's strategic documents and provisions concerning activities aimed at increasing the level of innovation in education. Then, the concepts characterising the pro-innovative attitude of man in the context of such concepts as creativity and innovation are discussed. Factors determining the proinnovation attitude were indicated. The main part of the article focuses on various areas of innovative activity of teachers and their attitude to creativity and creativity. Attention was paid to teachers' attitudes towards students' creative behaviour. An important element is an attempt to diagnose the factors shaping innovativeness of teachers - in terms of systems and personalities. The analysis used selected results of previous studies.
\end{abstract}

Dane do korespondencji:

Dr hab. Małgorzata Kamińska, prof. SWPW, Płock

Szkoła Wyższa im. Pawła Włodkowica w Płocku

e-mail: gosiam0@poczta.onet.pl 